\title{
Dopamine Transporter Expression Confers Cytotoxicity to Low Doses of the Parkinsonism-inducing Neurotoxin 1-Methyl-4-phenylpyridinium
}

\author{
Christian Pifl, Brunos Giros, and Marc G. Caron \\ Howard Hughes Medical Institute Laboratories, Department of Cell Biology, Duke University Medical Center, Durham, \\ North Carolina 27710
}

The uptake of 1-methyl-4-phenylpyridinium (MPP ${ }^{+}$), the active metabolite of the parkinsonism-inducing neurotoxin 1-methyl-4-phenyl-1,2,3,6-tetrahydropyridine (MPTP), was studied in various mammalian cell lines transfected, respectively, with the cloned human and rat dopamine transporters, and compared with rat striatal synaptosome preparations. Only in neuronally derived cell lines such as NG108-15, NS20Y, and SK-N-MC cells did MPP+ have a $K_{M}$ for the cloned transporters comparable to that of dopamine as seen in rat striatal synaptosomes. In non-neuronally derived cells such as COS-7, CHO, and Ltk ${ }^{-}$cells transiently or permanently expressing the transporters, the $K_{M}$ of MPP+ was at least 10fold higher. The permanent expression of either the cloned human or rat dopamine transporters conferred to SK-N-MC cells susceptibility to the cytotoxic effects of low concentrations of MPP+. The extent of this effect was dependent on the expression level of the dopamine transporters and could be specifically antagonized by the catecholamine uptake inhibitor mazindol. There were no significant differences in the susceptibility to MPP+ of cells expressing similar levels of either the human or rat dopamine transporter. The demonstration for the first time of a quantitative relationship between the cellular expression of the plasma membrane transporter and the extent of the cytotoxic effects of MPP+ suggests that known differences in vulnerability of various brain regions to MPP+ cytotoxicity might be related to their actual content of dopamine uptake sites. In addition, our results suggest that intrinsic differences in the dopamine transporter proteins of humans and rats are probably not responsible for the marked increased susceptibility of primates to the neurotoxic effects of MPTP, as compared to rats.

[Key words: human dopamine transporter, rat dopamine transporter, MPTP (1-methyl-4-phenyl-1,2,3,6-tetrahydropyridine), MPP+ (1-methyl-4-phenylpyridinium ion), cytotoxicity, dopamine uptake, MPP+ uptake, parkinsonism, transfection, cell culture]

\footnotetext{
Received Jan. 29, 1993; revised Apr. 20, 1993; accepted Apr. 29, 1993.

This work was supported in part by Grants NS-15976, IP-53-NIH 44221, and MH-40159 from the National Institutes of Health, Bethesda, MD, to M.C.G., by NARSAD Young Investigator Fellowship to B.G., and by J0745-MED from the Austrian Science Foundation, Vienna, to C.P. We thank Nathalie Godinot for expert technical assistance.

Correspondence should be addressed to Christian Pifl at his present address: Institute of Biochemical Pharmacology, University of Vienna, Borschkegasse 8A, 1090 Vienna, Austria.

Copyright (C) 1993 Society for Neuroscience $0270-6474 / 93 / 134246-08 \$ 05.00 / 0$
}

1-Methyl-4-phenyl-1,2,3,6-tetrahydropyridine (MPTP) produces parkinsonism in human and subhuman primates by a neurotoxic effect on dopaminergic neurons in the nigrostriatal pathway (Davis et al., 1979; Burns et al., 1983; Langston et al., 1983, 1984). MPTP is bioactivated in the brain by its oxidation to 1-methyl-4-phenylpyridinium ion $\left(\mathrm{MPP}^{+}\right)$, catalyzed by monoamine oxidase B (MAO-B) (Chiba et al., 1984; Heikkila et al., 1984b; Langston et al., 1984; Markey et al., 1984; Salach et al., 1984). A key event in the expression of the neurotoxicity of MPTP is the active uptake of $\mathrm{MPP}^{+}$into dopaminergic neurons as revealed by the protective effect of dopamine uptake blockers in MPTP-treated mice and monkeys (Javitch et al., 1985; Melamed et al., 1985; Schultz et al., 1986). Low doses of MPTP kill dopaminergic neurons in the substantia nigra of primates (Burns et al., 1983; Langston et al., 1984), much higher doses are required in mice (Heikkila et al., 1984a; Wallace ct al., 1984), and the rat is nearly insensitive to peripherally administered MPTP (Boyce et al., 1984; Sahgal et al., 1984). Several hypotheses about the differences in susceptibility of these species have been emphasized: differences in MPTP-binding sites, that is, MAO-B, in the substantia nigra (Javitch et al., 1984b; O'Carroll et al., 1987), differences in $\mathrm{MPP}^{+}$-binding neuromelanin (D'Amato et al., 1986), and differences in MPTPmetabolizing MAO-B activity in the capillary wall of brain blood vessels (Kalaria and Harik, 1987).

Another possibility that has not been examined is that differences in the intrinsic properties of the uptake systems of these species exist with respect to MPP+ as an uptake substrate. Until recently, the only model system for dopamine transport has been striatal synaptosomes. Comparative studies of rat versus human dopamine transport have been hampered by the problems in studying synaptosomal uptake in human tissue, that is, postmortem tissue. The cloning of both rat (Giros et al., 1991; Kilty et al., 1991; Shimada et al., 1991) and human dopamine transporters (Giros et al., 1992) allows controlled comparison of both uptake systems by expressing the cDNA and assaying the expressed transporter in the same cellular system (Giros et al., 1992). Besides the protective influence of dopamine uptake blockers on $\mathrm{MPP}^{+}$toxicity, it has never been demonstrated that toxicity is correlated directly with the expression of the dopamine transporter protein. Therefore, in order to examine these issues, we studied the uptake of ${ }^{3} \mathrm{H}$-dopamine and ${ }^{3} \mathrm{H}-\mathrm{MPP}+$ in various types of cells expressing various levels of either the cloned rat or the human dopamine transporter and examined cytotoxic effects of $\mathrm{MPP}^{+}$on such cell lines. To validate our uptake experiments we also measured transport in the classical model system of rat striatal synaptosomes. 


\section{Materials and Methods}

Materials. Sprague-Dawley rats were from Charles River. Media, sera, and other tissue culture reagents were obtained from GIBCO-Bethesda Research Labs. Drugs were obtained from Research Biochemicals, Inc. Radiochemicals were from New England Nuclear.

Synaptosomal preparation. Fresh crude synaptosomes were prepared according to the method described by Javitch et al. (1985) with minor modifications. Male Sprague-Dawley rats $(250-350 \mathrm{gm})$ were killed by decapitation and the brains were chilled for $5 \mathrm{~min}$ in ice-cold PBS. The striatum was dissected at $4^{\circ} \mathrm{C}$ from 1 -mm-thick coronal slices on an ice-chilled glass plate and homogenized in $15 \mathrm{vol}(\mathrm{gm} \mathrm{tissue} / \mathrm{ml}$ ) of icecold $0.3 \mathrm{M}$ sucrose in a tapered glass tissue grinder with a Teflon pestle (clearance of the cylindrical section, $0.1-0.15 \mathrm{~mm}$; Wheaton). The homogenate was diluted $1: 3$ in $0.3 \mathrm{M}$ sucrose and centrifuged at $1000 \times$ $g$ for $10 \mathrm{~min}$. The supernatant was centrifuged at $12,000 \times g$ for 20 $\mathrm{min}$. The second pellet was resuspended in $30 \mathrm{vol}$ of $0.3 \mathrm{M}$ sucrose and used for uptake experiments.

Cell culture. COS-7 (African green monkey kidney), Ltk- (mouse fibroblast), CHO (Chinese hamster ovary), NG 108-5 (mouse neuroblastoma $\times$ rat glioma hybrid), and NS20Y (mouse neuroblastoma) cells were grown in Dulbecco's modified Eagle's medium with L-glutamine and $4500 \mathrm{mg} /$ liter D-glucose; the medium of COS-7 and Ltkcells also contained $10 \%$ hcat-inactivated fetal bovine serum and $50 \mu \mathrm{g} /$ $\mathrm{ml}$ gentamicin; that of NG108-15 cells, $5 \%$ heat-inactivated fetal bovine serum, $0.1 \mathrm{~mm}$ sodium hypoxanthine, $16 \mu \mathrm{M}$ thymidine, and $1 \mu \mathrm{M}$ aminopterin. Media for NS20Y cells contained $10 \%$ heat-inactivated fetal bovine serum and $110 \mathrm{mg} /$ liter sodium pyruvate. SK-N-MC (human neuroblastoma) cells were grown in minimum essential medium with Earle's salts and L-glutamine, $10 \%$ heat-inactivated fetal bovine serum, and $50 \mu \mathrm{g} / \mathrm{ml}$ gentamicin. All cells were grown in $100-$ or 150 $\mathrm{mm}$-diameter tissue culture dishes (polystyrene, Falcon) at $37^{\circ} \mathrm{C}$ under an atmosphere of $5 \% \mathrm{CO}_{2}, 95 \%$ air, or in case of NS20Y cells under an atmosphere of $10 \% \mathrm{CO}_{2}, 90 \%$ air.

Cell line transfection. The rat and human dopamine transporter cDNAs were used in the expression vector pCMV5 (Giros et al., 1991, 1992) for establishing the stable $\mathrm{Ltk}^{-}$cell lines, whereas the human transporter cDNA was subcloned into $\mathrm{pRc} / \mathrm{CMV}$ (Invitrogen Corporation) for transfection of all other cell lines. In order to obtain the human dopa mine transporter in $\mathrm{pRc} / \mathrm{CMV}$, the cDNA subcloned in pBluescript (Giros et al., 1992) was amplified by polymerase chain reaction (PCR) as described (Giros et al., 1989) with two primers flanking the coding region. The primer in $5^{\prime}$ contained an Hind III site (GTAAAGCTTC AACTCCCAGTGTGCCCATG) whereas the primer in 3 ' contained an Xba I site (GCGTCTAGACTTCCTGGGGTCTTCGTCTCTG). The amplified DNA was excised with the appropriate restriction enzymes and directionally subcloned into the corresponding sites of $\mathrm{pRc} / \mathrm{CMV}$. One clone was amplified and sequenced to check that there were no PCR errors. This clone was used for all the following transfections. For transient expression DEAE-dextran transfection was used for COS-7 and NS20Y cells, and calcium phosphate transfection was used for SK-N-MC and NG108-15 cells; $3 \times 10^{6}$ cells were inoculated in 100mm-diameter dishes $1 \mathrm{~d}$ (COS-7, NG108-15 cells) or $2 \mathrm{~d}$ (NS20Y, SK$\mathrm{N}-\mathrm{MC}$ cells) before the transfection procedure. The DEAE-dextran transfection was started by washing the cells with PBS; then cells were incubated for $30 \mathrm{~min}$ with $5 \mathrm{ml}$ of PBS containing $2.5 \mathrm{mg}$ of DEAEdextran and $15 \mu \mathrm{g}$ of DNA at $37^{\circ} \mathrm{C}$ in the incubator. Twenty milliliters of medium containing $1.032 \mathrm{mg}$ of chloroquine were then added and the cells incubated for $2.5 \mathrm{hr}$. After removing the medium, cells were treated for $2.5 \mathrm{~min}$ with $5 \mathrm{ml}$ of medium containing $15 \%$ dimethyl sulfoxide, and incubated in medium overnight. The next morning cells from two $100-\mathrm{mm}$-diameter plates were distributed into three 24 -well plates for uptake studies, which were carried out $2 \mathrm{~d}$ later. The calcium phosphate transfection was done according to the supplier's instruction (CellPhect transfection kit, Pharmacia). The cells of two $100-\mathrm{mm}$-diameter plates were distributed into threc 24-well plates on the day after transfection. For stable transfection the calcium phosphate transfection system from Bethesda Research Labs was used; $1 \times 10^{6}$ cells were plated into 100-mm-diameter cell culture dishes $1 \mathrm{~d}\left(\mathrm{Ltk}^{-}, \mathrm{CHO}\right)$ or $2 \mathrm{~d}$ (SK$\mathrm{N}$-MC) before transfection; $15 \mu \mathrm{g}$ of human or rat dopamine transporter cDNA subcloned into pCMV 5, $0.75 \mu \mathrm{g}$ of pRSVNeo, and $5 \mu \mathrm{g}$ of carrier DNA (salmon sperm DNA) were used per 100 -mm-diameter dish of $\mathrm{Ltk}^{-}$and $\mathrm{CHO}$ cells. SK-N-MC cells were transfected either with $15 \mu \mathrm{g}$ of rat dopamine transporter cDNA subcloned into pCMV5, $0.75 \mu \mathrm{g}$ of pRSVNeo, and $5 \mu \mathrm{g}$ of carrier DNA, or with $15 \mu \mathrm{g}$ of human dopamine transporter subcloned into $\mathrm{pRc} / \mathrm{CMV}$ and $5 \mu \mathrm{g}$ of carrier DNA. The day after transfection, cells were transferred into $150-\mathrm{mm}$-diameter dishes and were selected using $0.8 \mathrm{gm} /$ liter $\mathrm{G} 418$ for $\mathrm{Ltk}^{-}$and $\mathrm{CHO}$ cells and $1 \mathrm{gm} /$ liter G418 for SK-N-MC cells. For uptake experiments cells were distributed into 24-well plates and the uptake was measured 2-3 d later.

Uptake into striatal synaptosomes. Twenty-five microliters of the synaptosomal suspension were added to $600 \mu \mathrm{l}$ of uptake buffer $(4 \mathrm{mM}$ Tris- $\mathrm{HCl}, 6.25 \mathrm{~mm}$ HEPES, $120 \mathrm{~mm} \mathrm{NaCl}, 5 \mathrm{~mm} \mathrm{KCl}, 1.2 \mathrm{~mm} \mathrm{CaCl}$, $1.2 \mathrm{mM} \mathrm{MgSO}_{4}, 5.6 \mathrm{~mm}$ D-glucose, $0.5 \mathrm{~mm}$ ascorbic acid, final $\mathrm{pH} 7.1$ ) containing $0.14 \mu \mathrm{Ci}$ of ${ }^{3} \mathrm{H}$-dopamine $\left(28 \mathrm{Ci} / \mathrm{mmol}\right.$ ) or $0.44 \mu \mathrm{Ci}$ of ${ }^{3} \mathrm{H}$ $\mathrm{MPP}^{+}(84 \mathrm{Ci} / \mathrm{mmol})$ and various concentrations of the drugs to be tested. After an incubation at $37^{\circ} \mathrm{C}$ for $5 \mathrm{~min}$ the uptake was stopped by the addition of $5 \mathrm{ml}$ of ice-cold uptake buffer and immediate filtration through Whatman GF/B glass-fiber filters presoaked in $0.05 \%$ polyethylenimine. The filters were washed twice with $5 \mathrm{ml}$ of ice-cold buffer and analyzed for tritium radioactivity in a Packard Tricarb 2000 CA liquid scintillation counter. Nonspecific uptake was estimated in the presence of $10 \mu \mathrm{M}$ mazindol.

Uptake into cells. Uptake experiments were performed in 24-well plates. The uptake buffer was the same as was used for uptake into synaptosomes (see above). Each well was washed with $0.5 \mathrm{ml}$ of buffer and incubated with $0.25 \mathrm{ml}$ of buffer containing $0.7 \mu \mathrm{Ci}$ of ${ }^{3} \mathrm{II}$-dopamine $(28 \mathrm{Ci} / \mathrm{mmol})$ or $2.2 \mu \mathrm{Ci}$ of ${ }^{3} \mathrm{H}-\mathrm{MPP}+(84 \mathrm{Ci} / \mathrm{mmol})$ and various concentrations of drugs for $5 \mathrm{~min}$. Uptake was stopped by aspirating the uptake buffer and washing each well twice with $1 \mathrm{ml}$ of buffer. The radioactivity remaining in each well was determined by incubating with $0.4 \mathrm{ml}$ of $1 \%$ SDS and transferring this solution into scintillation vials containing $10 \mathrm{ml}$ of scintillation cocktail (Research Biochemicals Inc.).

Toxicity studies. Cells were distributed into 12-well plates (Ltk ${ }^{-}$cells, $0.1 \times 10^{6}$ cells/well; SK-N-MC cells, $0.08 \times 10^{6}$ cells/well) and $3 \mathrm{~d}$ later different concentrations of $\mathrm{MPP}^{+}$and/or mazindol or vehicle was added for various times. After the exposure, cells were recovered by detaching them with trypsin/EDTA and $1 \mathrm{ml}$ of cell suspension was incubated with $2 \mu$ l of a saturated solution of the viability dye fluorescein diacetate in absolute ethanol (Rotman and Papermaster, 1966). The fluorescent cells were visualized under the fluorescence microscope and counted using a hemocytometer.

Data analysis. $V_{\max }, K_{M}$, and $K_{i}$ values were calculated by the iterative curve-fitting programs EBDA and LIGAND (McPherson, 1985).

\section{Results}

To compare uptake by the cloned transporters with the classical model of dopamine transport, synaptosomes from rat striatum were prepared. Dopamine and $\mathrm{MPP}^{+}$were taken up by striatal synaptosomes with a $K_{M}$ or $0.1 \mu \mathrm{M}$ and $0.3 \mu \mathrm{M}$, respectively. The $V_{\max }$ of $\mathrm{MPP}^{+}$uptake was about half of that of dopamine uptake (Fig. 1).

The rank order of potency of drugs inhibiting uptake of dopamine by the synaptosomal preparations (Table 1) was typical for a dopamine transporter: high affinity of the selective dopamine uptake blockers GBR 12909 and benztropine and low affinity of potent blockers of 5-HT uptake-clomipramine-and noradrenaline uptake-desipramine. The $K_{i}$ values of MPP+ for the dopamine transporter were in the same range as those of dopamine and noradrenaline.

The cloned rat and human dopamine transporters were expressed permanently in the same cell line, that is, $\mathrm{Ltk}^{-}$cells. Uptake of dopamine and $\mathrm{MPP}^{+}$was assayed under the same conditions as used for striatal synaptosomes. Transfected cell lines with comparable transport capacity for dopamine were sludied and usually displayed an uptake of ${ }^{3} \mathrm{H}$-dopamine or ${ }^{3} \mathrm{H}$ $\mathrm{MPP}^{+}$that was 10-20-fold higher than that observed in the presence of $10 \mu \mathrm{M}$ mazindol or in untransfected cells. In isotopic dilution experiments the $K_{M}$ of $\mathrm{MPP}^{+}$for both rat and human dopamine transporters was much higher than that of dopamine (Fig. 2). In addition, the $K_{M}$ of dopamine for the cloned transporters was significantly higher than that found in synaptosomal preparations. The $V_{\text {max }}$ of $\mathrm{MPP}^{+}$was not significantly different from that of dopamine, whereas the ratio of $K_{M}$ values $-K_{M}$ of 


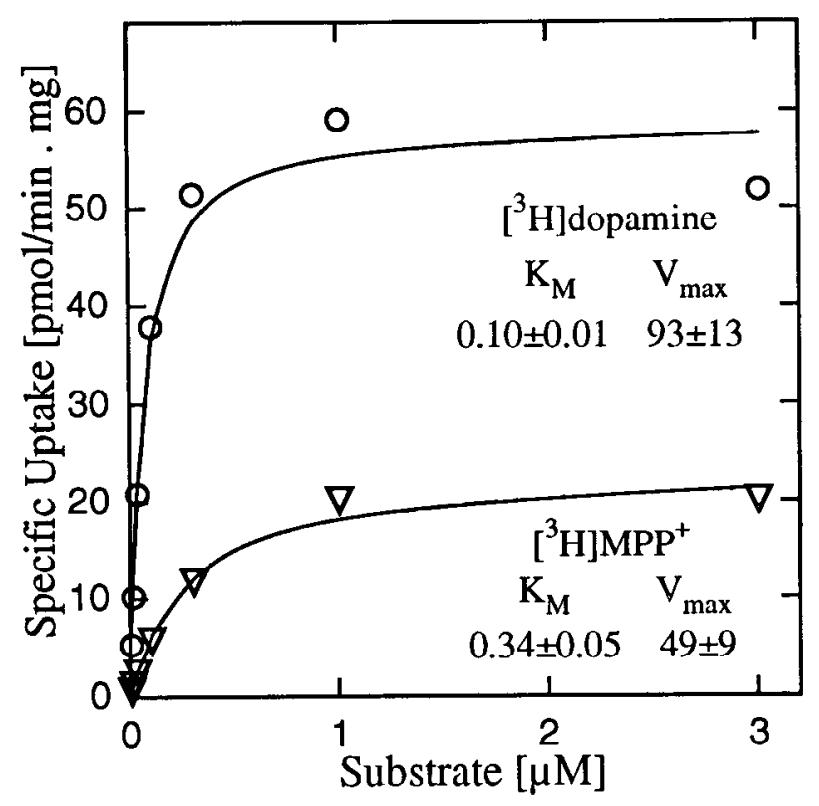

Figure 1. Uptake of ${ }^{3} \mathrm{H}$-dopamine and ${ }^{3} \mathrm{H}-\mathrm{MPP}+$ into rat striatal synaptosomes. The synaptosomal preparation (15-25 $\mu \mathrm{g}$ protein/tube) was incubated with $0.14 \mu \mathrm{Ci}$ of ${ }^{3} \mathrm{H}$-dopamine or $0.44 \mu \mathrm{Ci}$ of ${ }^{3} \mathrm{H}-\mathrm{MPP}+$ and various concentrations $(0.03-10 \mu \mathrm{M})$ of dopamine or $\mathrm{MPP}^{+}$, respectively, for $5 \mathrm{~min}$ at $37^{\circ} \mathrm{C}$ as described in Materials and Methods. Nonspecific uptake was measurcd in the presence of $10 \mu \mathrm{M}$ mazindol. Shown is a representative saturation experiment, as well as the mean $\pm \mathrm{SE} K_{M}$ $(\mu \mathrm{M})$ and $V_{\max }(\mathrm{pmol} / \mathrm{min} \cdot \mathrm{mg}$ protein) of five independent experiments.

$\mathrm{MPP}^{+}$versus that of dopaminc-was ncarly 10 . There was no significant species difference. In these cells the rank order of potency of uptake blockers was consistent with a specific dopamine transport system: high affinity of GBR 12909 and benztropine, low affinity of clomipramine and desipramine (Table 1). Another substrate besides $\mathrm{MPP}^{+}$with high $K_{M}$ for the cloned transporters was noradrenaline.

Lik cells expressing the cloned transporters were exposed to $\mathrm{MPP}^{+}$in the culture medium in concentrations up to $300 \mu \mathrm{M}$ for up to $7 \mathrm{~d}$. There was no difference in viability of these cells compared to untransfected $\mathrm{Ltk}^{-}$cells as tested by accumulation of fluorescein diacetate under the fluorescence microscope (data not shown). $\mathrm{MPP}^{+}$at $30 \mu \mathrm{M}$ for 3 or $7 \mathrm{~d}$, however, produced a

\begin{tabular}{|c|c|c|c|}
\hline \multirow[b]{2}{*}{ Inhibitor } & \multirow[b]{2}{*}{ Synaptosomes } & \multicolumn{2}{|c|}{ Cloned transporter } \\
\hline & & Rat & Human \\
\hline GBR 12909 & 4 & 13 & 17 \\
\hline Benztropine & 63 & 110 & 56 \\
\hline Dopamine $\left(K_{M}\right)$ & 93 & 2800 & 3200 \\
\hline Noradrenaline & 250 & 51,100 & 48,400 \\
\hline $\mathrm{MPP}^{+}$ & 322 & 40,700 & 31,300 \\
\hline Clomipramine & 2980 & $>1000$ & $>1000$ \\
\hline Desipramine & 6330 & 13,000 & 12,000 \\
\hline
\end{tabular}

${ }^{3} \mathrm{H}$-dopamine uptake competition experiments were performed by incubation of synaptosomes with $5 \mathrm{nM}$ and cells with $20 \mathrm{nM}{ }^{3} \mathrm{H}$-dopamine in the presence of various concentrations of the compounds for $5 \mathrm{~min}$ at $37^{\circ} \mathrm{C}$. Shown are mean $k$ ( $K_{1}$ for dopamine) values (nM) of three independent experiments with a standard error of $<7 \%$ of the values reported.

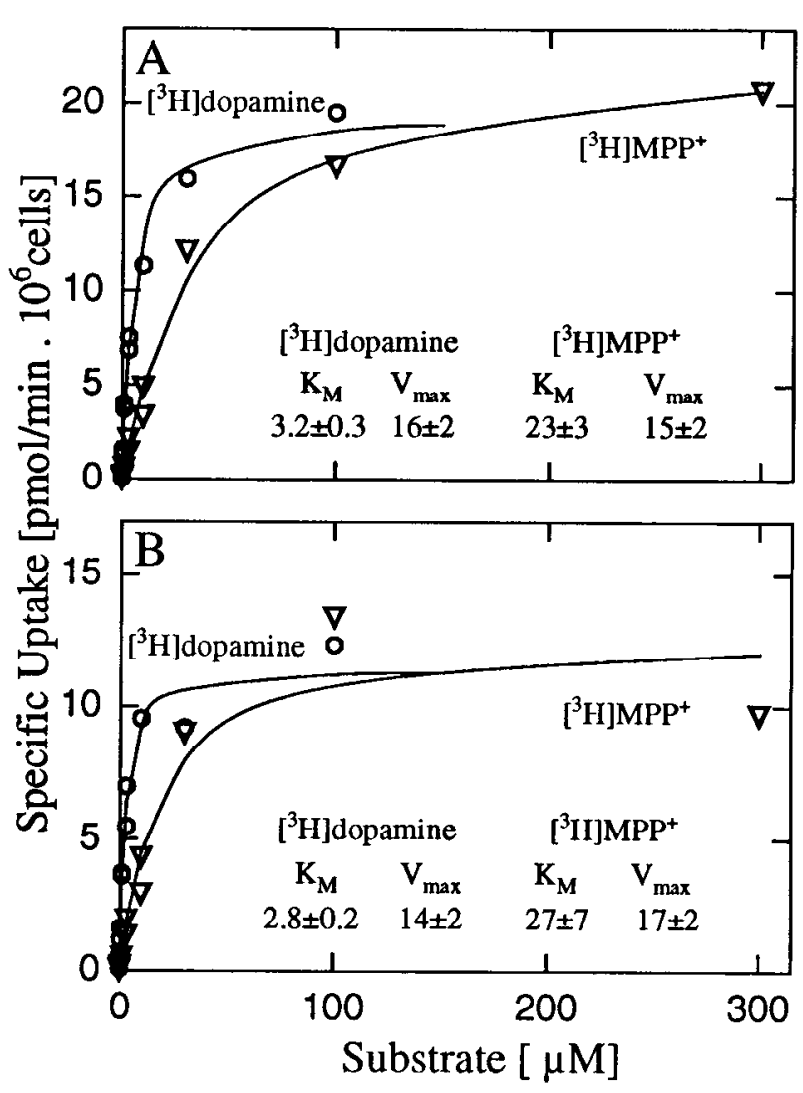

Figure 2. Uptake of ${ }^{3} \mathrm{H}$-dopamine and ${ }^{3} \mathrm{H}-\mathrm{MPP}^{+}$into Ltk- cells permanently transfected with the cloned human $(A)$ or rat $(B)$ dopamine transporter. The cells $\left(0.15-0.25 \times 10^{6}\right.$ cells/well $)$ were incubated with $0.7 \mu \mathrm{Ci}$ of ${ }^{3} \mathrm{H}$-dopamine or $2.2 \mu \mathrm{Ci}$ of ${ }^{3} \mathrm{H}-\mathrm{MPP}{ }^{+}$and various concentrations of dopamine $(0.3-30 \mu \mathrm{M})$ or $\mathrm{MPP}^{+}(1-300 \mu \mathrm{M})$, respectively, for $5 \mathrm{~min}$ at $37^{\circ} \mathrm{C}$ as described in Materials and Methods. Nonspecific uptake was measured in the presence of $10 \mu \mathrm{M}$ mazindol. Shown is a representative saturation experiment, as well as the mean $\pm \mathrm{SE} K_{M}(\mu \mathrm{M})$ and $V_{\max }\left(\mathrm{pmol} / \mathrm{min} \cdot 10^{6}\right.$ cells $)$ of four independent experiments.

change in $\mathrm{pH}$ of the culture medium of Ltk $^{-}$cells expressing the cloned transporters toward acidic values as compared to vehicle treatment. There were no significant $\mathrm{pH}$ changes in untransfected Ltk ${ }^{-}$cells (Fig. 3). At high concentrations of MPP+ $(300 \mu \mathrm{M})$ an acidification of the medium of untransfected Ltk cells was also observed. As a control, Ltk ${ }^{-}$cells transfected permanently with the $\mathrm{D}_{1 \mathrm{~A}}$ dopamine receptor (Dearry et al., 1990) instead of the dopamine transporters using the same expression vector and selection principle, that is, pCMV5 and neomycin, reacted to MPP ${ }^{+}$exposure similarly as untransfected Ltk- cells (data not shown).

Obviously, in vivo, the dopamine transporter is expressed in neuronal cells, not in fibroblast like cells as $\mathrm{Ltk}^{-}$. We therefore expressed the dopamine transporter in different cell types that, endogenously, were devoid of specific dopamine uptake (Table 2). In fact, whereas in all non-neuronal cell lines examined (transiently transfected COS-7 and permanently transfected $\mathrm{Ltk}^{-}$and CHO cells) $\mathrm{MPP}^{+}$showed a much higher $K_{i}$ value than the $K_{M}$ for dopamine (a ratio of about 10 ), in more neuronal-like cell types such as transiently transfected SK-N-MC, NS20Y, and NG108-15 this ratio of MPP+ versus dopamine was similar to that in striatal synaptosomes. The $K_{i}$ of noradrenaline was hardly shifted by the change of cellular expression system. Without transfection, all cell lines used showed an uptake of ${ }^{3} \mathrm{H}$-dopa- 


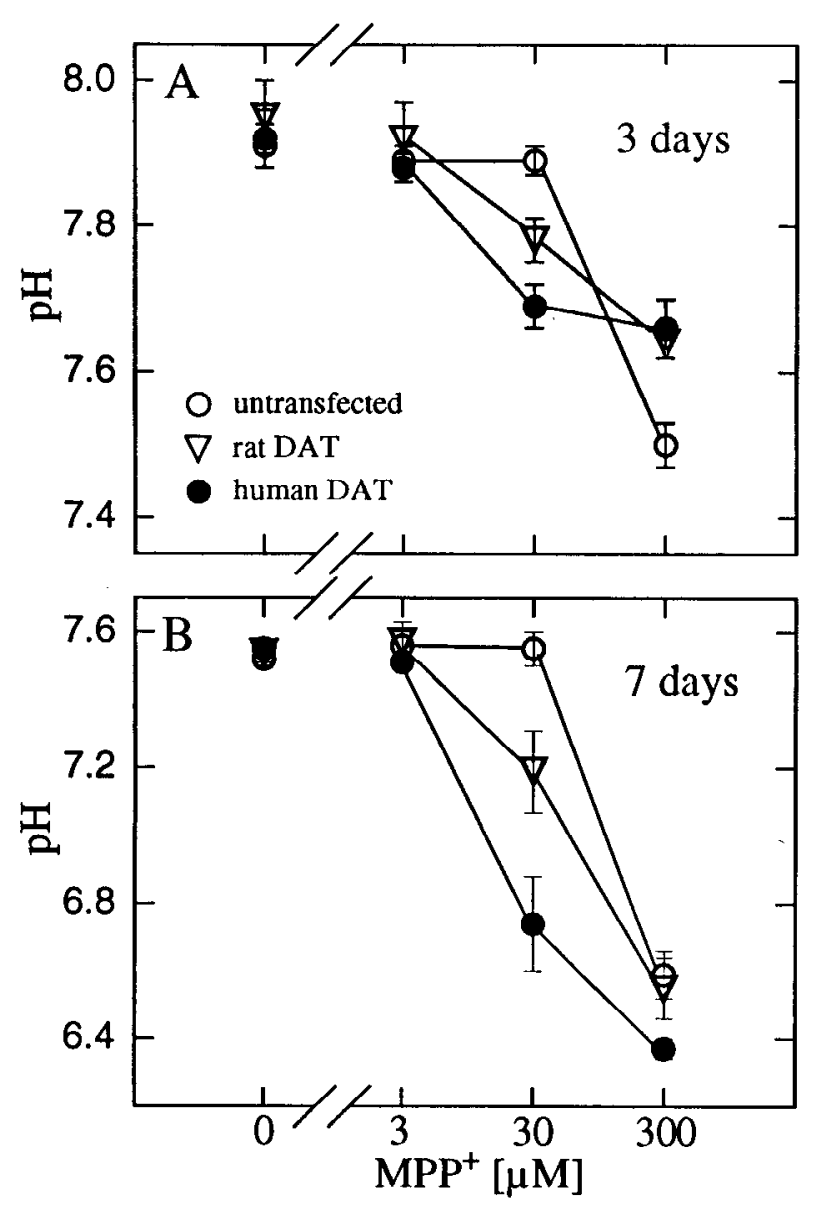

Figure 3. $\mathrm{pH}$ of the medium of Ltk- cells expressing the rat and human dopamine transporters $\left(D A^{\prime} I\right)$ after $\mathrm{MPP}^{+}$treatment. Untransfected Ltkcells (open circles) and $\mathrm{Ltk}^{-}$permanently expressing the cloned rat (triangles) and human (solid circles) dopamine transporter were distributed into 12 -well plates $\left(0.1 \times 10^{6}\right.$ cells $/$ well $)$ and $3 \mathrm{~d}$ later various concentrations of $\mathrm{MPP}^{+}$or vehicle were added to the medium. The $\mathrm{pH}$ of the medium of the cells was measured with a glass electrode after $3 \mathrm{~d}(A)$ or $7 \mathrm{~d}(B)$ of exposure to $\mathrm{MPP}^{+}$. Shown are mean values $\pm \mathrm{SE}$ of three or four independent experiments.

mine that was similar to that of transfected cells in the presence of $10 \mu \mathrm{M}$ mazindol. In addition, untransfected cells showed no difference in the nonspecific accumulation of $\mathrm{MPP}^{+}$(data not shown).

To study the effect of $\mathrm{MPP}^{+}$on neuronal cell lines expressing the dopamine transporters, we established SK-N-MC cell lines permanently expressing the dopamine transporters. Clones of different expression levels for rat and human dopamine transporters were obtained. Viability tests with fluorescein diacetate showed that $10 \mu \mathrm{M} \mathrm{MPP}^{+}$in the medium for $3 \mathrm{~d}$ had no effect on untransfected SK-N-MC cells (Fig. $4 A, B$ ). SK-N-MC cells permanently expressing the human dopamine transporter showed no differences in morphology as compared to wild-type but there was a decreased number of fluorescent cells after a $3 \mathrm{~d}$ treatment with $10 \mu \mathrm{M} \mathrm{MPP}+$ (Fig. $4 C, D$ ). The remaining fluorescent cells were of more elongated and spindly shape than the treated wildtype and untreated transfected cells. Cell counting in the hemocytometer after detaching the cells (Fig. 5) revealed toxic effects of MPP+ at concentrations of $1 \mu \mathrm{M}$ for $3 \mathrm{~d}$ on cells expressing the highest level of uptake activity $\left(50\right.$ or $82 \mathrm{pmol} / \mathrm{min} \cdot 10^{6}$ cells for rat or human dopamine transporter, respectively). MPP + in concentrations of $0.1-10 \mu \mathrm{M}$ in the medium for 3 or $6 \mathrm{~d}$ had no
Table 2. Human dopamine transporter in different cell lines

\begin{tabular}{|c|c|c|c|}
\hline & $\begin{array}{l}\text { Dopamine } \\
K_{M}(\mu \mathrm{M})\end{array}$ & $\begin{array}{l}\mathrm{MPP}^{+} \\
K_{i}(\mu \mathrm{M})\end{array}$ & $\begin{array}{l}\text { Noradrenaline } \\
K_{i}(\mu \mathrm{M})\end{array}$ \\
\hline COS-7 & $3.9 \pm 0.7(3)$ & $23 \pm 2$ & $48 \pm 5(3)$ \\
\hline Ltk $^{-}$ & $2.9 \pm 0.4(5)$ & $31 \pm 6$ & $48 \pm 3(3)$ \\
\hline $\mathrm{CHO}$ & 2.2 & 39 & $35 \quad$ (1) \\
\hline SK-N-MC & $1.2 \pm 0.2(3)$ & $3.7 \pm 1.0(3)$ & $21,19(2)$ \\
\hline NS $20 \mathrm{Y}$ & $1.6 \pm 0.3(3)$ & $3.0 \pm 1.1(3)$ & $19 \pm 3(3)$ \\
\hline NG $108-15$ & $3.1 \pm 0.5(3)$ & $5.1 \pm 1.5(3)$ & $31,40(2)$ \\
\hline
\end{tabular}

$\overline{{ }^{3} \text { H-dopamine uptake competition experiments were performed by incubation of }}$ the transfected cells with $20 \mathrm{nM}{ }^{3} \mathrm{H}$-dopamine in the presence of various concentrations of dopamine, MPP ${ }^{+}$, or noradrenaline for $5 \mathrm{~min}$ at $37^{\circ} \mathrm{C}$. Shown are mean values $\pm \mathrm{SE}$ of $(n)$ independent experiments.

toxic effects on untransfected SK-N-MC cells. MPP ${ }^{+}$at $100 \mu \mathrm{M}$ had toxic effects after $6 \mathrm{~d}$ of exposure. Cells expressing a low uptake activity $\left(0.9 \mathrm{pmol} / \mathrm{min} \cdot 10^{6}\right.$ cells $)$ after transfection with the cDNA of the human dopamine transporter showed a decreased viability in $100 \mu \mathrm{M} \mathrm{MPP}{ }^{+}$after $3 \mathrm{~d}$ of exposure and in $10 \mu \mathrm{M} \mathrm{MPP}^{+}$after $6 \mathrm{~d}$ exposure. Thus, there appears to be a direct correlation between the expression level of the dopamine transporter and the MPP+ cytotoxicity. The toxicity of 1 and $10 \mu \mathrm{M} \mathrm{MPP}^{+}$in the highly expressing cells could be blocked by the catecholamine uptake inhibitor mazindol dose dependently (Fig. 6).

\section{Discussion}

Our study examined the properties of the cloned dopamine transporter as an influx pathway for $\mathrm{MPP}^{+}$, the toxic agent proper of the parkinsonism-inducing neurotoxin MPTP. The importance of the dopamine uptake system for the toxicity of MPTP has been suggested in several reports (Pileblad and Carlsson, 1985; Ricaurte et al., 1985; Sundström and Jonsson, 1985; Mayer et al., 1986) but never with respect to species differences and in systems where the total absence of the transporter could be tested. The expression of the cloned human and rat transporters in cell lines allowed us a controlled comparison of the protein of these species, avoiding the imponderables of postmortem artifacts using striatal synaptosomes. In this model system, there were no significant differences in the handling of $\mathrm{MPP}^{+}$by the transporters of the two species. Therefore, our results suggest that differences in the susceptibility of these two species to toxic effects of MPTP cannot be due to differences in intrinsic properties of their respective dopamine transporter.

A puzzling finding, though, was the high $K_{M}$ of $\mathrm{MPP}^{+}$for the cloned transporters. Furthermore, the transporter did not confer to the $\mathrm{Ltk}^{-}$cells a high sensitivity to $\mathrm{MPP}^{+}$. Ltk ${ }^{-}$cells expressing the rat or the human dopamine transporter, exposed to MPP ${ }^{+}$ in concentrations up to $300 \mu \mathrm{M}$ in the medium, did not die but showed a response consistent with a switch to anaerobic metabolism after shutting off the mitochondrial respiration by MPP ${ }^{+}$ (Vyas et al., 1986): an acidification of the medium at concentrations of MPP ' that did not affect untransfected Ltk cells. In agreement with our $K_{M}$ or $K_{i}$ data, a rather high concentration of MPP+, $30 \mu \mathrm{M}$, was necessary to observe this effect. Since the dopamine transporter in vivo is confined to neuronal cells, we expressed its cDNA in neuroblastoma-derived cell lines. In fact, there was a clear difference between non-neuronal COS-7, $\mathrm{Ltk}^{-}$, and $\mathrm{CHO}$ cells on the one hand and neuroblastoma-derived NG108-15, NS20Y, and SK-M-MC cells on the other in the handling of $\mathrm{MPP}^{+}$by the expressed dopamine transporter: the 

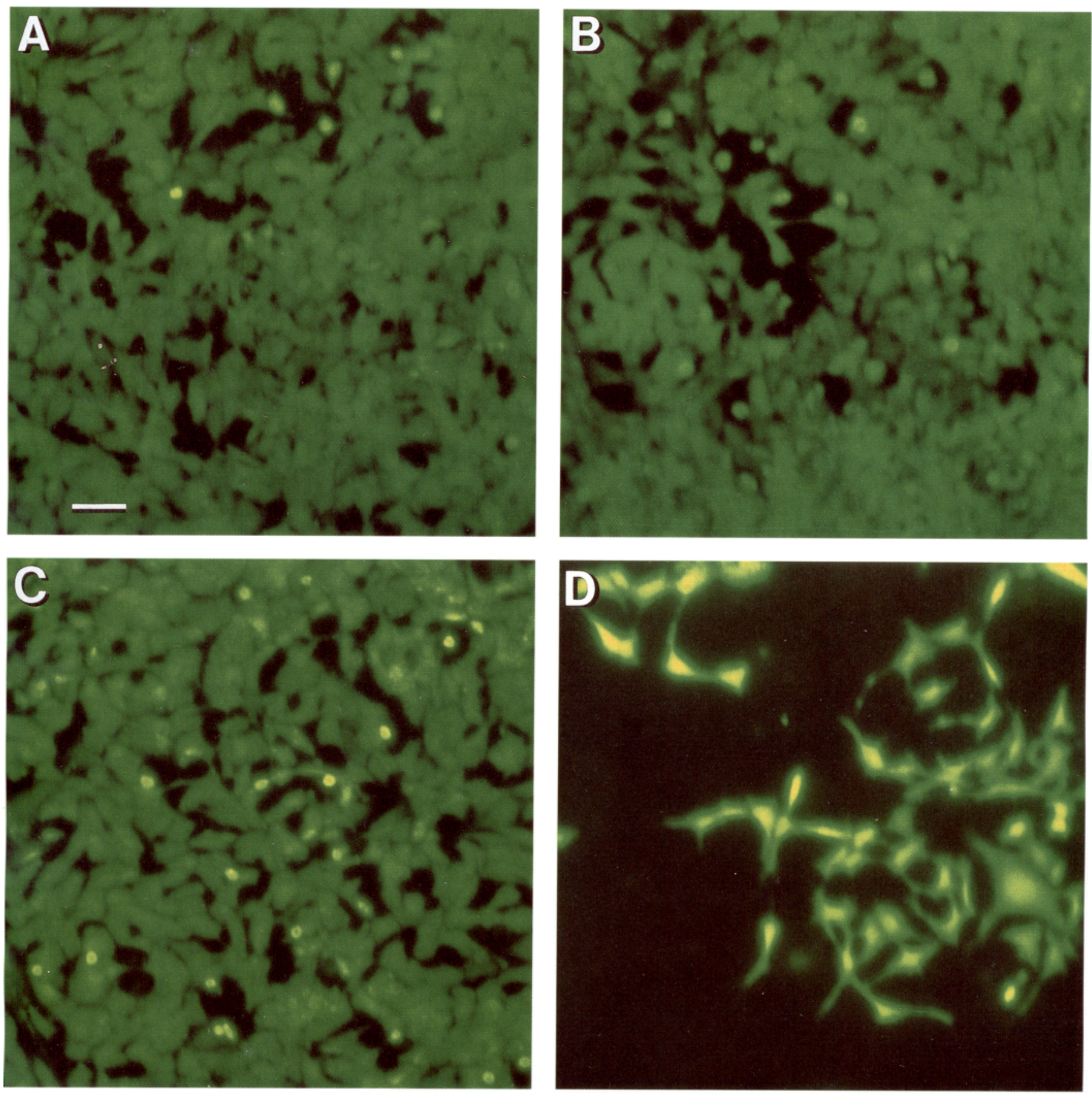

Figure 4. Effect of MPP+ exposure on the viability of SK-N-MC cells expressing the human dopamine transporter: fluorescence photomicrographs of untransfected SK-N-MC cells $(A, B)$ and SK-N-MC cells transfected with the human dopamine transporter $(C, D)$ stained with the viability dye fluorescein diacetate. Untransfected cells and cells expressing an uptake activity of $82 \mathrm{pmol} / \mathrm{min} \cdot 10^{6}$ cells $\left(V_{\max }\right)$ were distributed in six-well plates $\left(0.17 \times 10^{6}\right.$ cells/well) and $3 \mathrm{~d}$ later vehicle $(A, C)$ or $10 \mu \mathrm{M} \mathrm{MPP}+(B, D)$ was added to the medium. After $4 \mathrm{~d}$ of exposure cells were incubated with fluorescein diacetate in fresh medium for $10 \mathrm{~min}$, the medium was removed, and living cells were visualized under the fluorescence microscope. Scale bar, $20 \mu \mathrm{m}$.

$K_{i}$ of $\mathrm{MPP}^{+}$was lower in neuronal-like cells and similar to that of dopamine, resulting in a $K_{i}$ ratio comparable to that in rat striatal synaptosomes. This change was the result of only the $K$ of $\mathrm{MPP}^{+}$being shifted considerably by the choice of expression system rather than that of the substrates dopamine or noradrenaline. This shift in $K_{i}$ values can be due to a shift in the intrinsic affinity of $\mathrm{MPP}^{+}$for the transporter. It is also possible that the cell membrane structure or posttranslational modifications in neuronal-like versus non-neuronal cclls affect the transport of a lipophilic cation like $\mathrm{MPP}^{+}$more than that of primary amines like dopamine or noradrenaline.

One general property of the cloned transporter expressed in cell lines is that the $K_{M}$ of substrates (i.e., compounds actually taken up by the transporter such as dopamine, MPP+, and noradrenaline) are generally higher than in synaptosomal preparations. This property is also apparent if one examines previous 


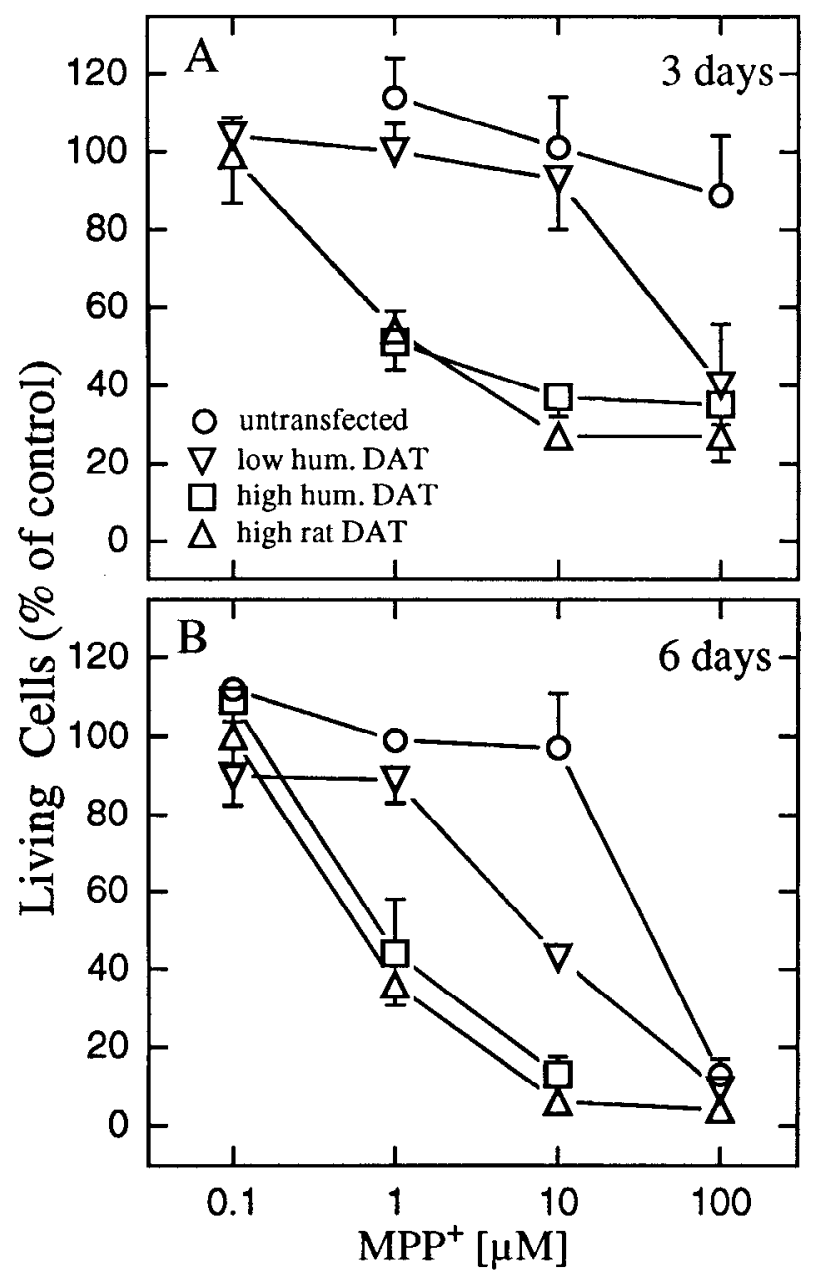

Figure 5. Toxicity of MPP+ $\mathrm{M}^{+}$SK-N-MC cells expressing the dopamine transporter (DAT). Untransfected SK-N-MC cells (circles) and SK$\mathrm{N}-\mathrm{MC}$ cells permanently expressing the cloned human ( $V_{\max }$ of dopamine uptake: $0.9 \mathrm{pmol} / \mathrm{min} \cdot 10^{6}$ cells, inverted triangles; $82 \mathrm{pmol} / \mathrm{min}$ $10^{6}$ cells, squares $)$, and rat $\left(50 \mathrm{pmol} / \mathrm{min} \cdot 10^{6}\right.$ cells, triangles $)$ dopamine transporter were distributed into 12 -well plates $\left(0.08 \times 10^{6}\right.$ cells/well) and $3 \mathrm{~d}$ later various concentrations of $\mathrm{MPP}^{+}$or vehicle were added to the medium. After $3 \mathrm{~d}(A)$ or $6 \mathrm{~d}(B)$ of exposure, cells were recovered by detaching them with trypsin/EDTA, incubated with fluorescein diacetate, and fluorescent cells were counted with a hemocytometer under the fluorescence microscope. Shown are mean values $\pm S E$ of fluorescent cells expressed as percentage of vehicle-treated cells from three or four independent experiments.

reports for the rat dopamine transporter expressed in Xenopus oocytes (Shimada et al., 1991) and HeLa cells (Kilty et al., 1991) as well as for the noradrenaline transporter expressed in HeLa cells (Javitch et al., 1984a; Richelson and Pfenning, 1984; Pacholczyk et al., 1991). In our hands, we have also found the same relationship for the human noradrenaline transporter (gift of Dr. S. Amara, Vollum Institute, Portland, OR) expressed in COS-7 cells using the expression vector $\mathrm{pRc} / \mathrm{CMV}$ as compared to rat synaptosomes (data not shown). A general shift in $K_{M}$ of substrates for transporter proteins in transfected cells could be due to the different diffusion conditions of the substrate molecules, one-dimensional in case of transport into plated cells, threedimensional in case of transport into spherical and much smaller synaptosomes. Alternatively, such differences might be due to potential differences (posttranslational modification, phosphorylation, protein-protein interactions) that might exist in the

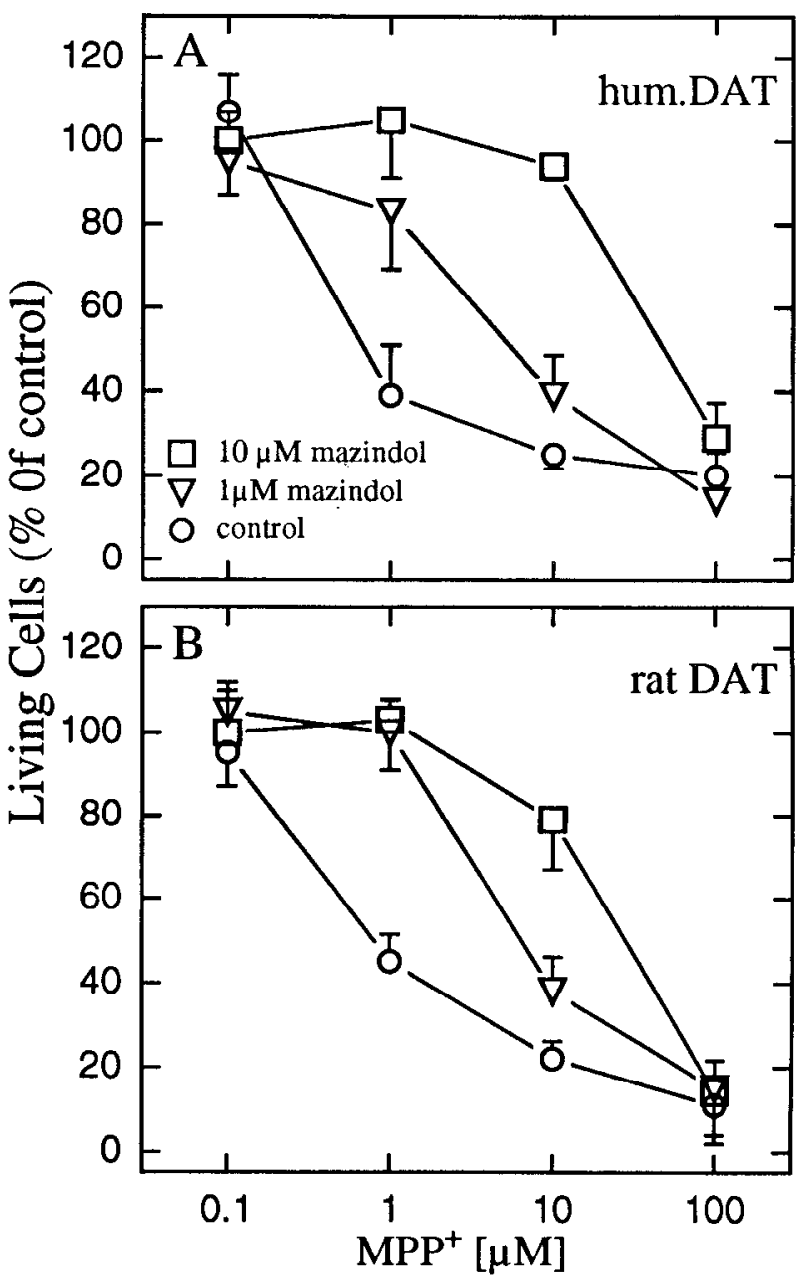

Figure 6. Blockade of the toxicity of $\mathrm{MPP}^{+}$by mazindol. SK-N-MC cells expressing the cloned human $\left(A ; 82 \mathrm{pmol} / \mathrm{min} \cdot 10^{6}\right.$ cells $)$ and the rat $\left(B ; 50 \mathrm{pmol} / \mathrm{min} \cdot 10^{6}\right.$ cells) dopamine transporter $(D A T)$ were distributed into 12 -well plates $\left(0.08 \times 10^{6}\right.$ cells/well $)$ and $3 \mathrm{~d}$ later, vehicle (circles) or $1 \mu \mathrm{M}$ (triangles) or $10 \mu \mathrm{M}$ (squares) mazindol and various concentrations of $\mathrm{MPP}^{+}$were added to the medium. After $4 \mathrm{~d}$ of exposure cells were recovered by detaching them with trypsin/EDTA, incubated with fluorescein diacetate, and fluorescent cells were counted with a hemocytometer under the fluorescence microscope. Shown are mean values $\pm \mathrm{SE}$ of fluoresecnt cells cxpressed as percentage of vehicletreated cells from three or four independent experiments.

structural organization of the transporter at the synapse as compared to our cell models.

The dopamine transporter-expressing cells showed susceptibility to lower concentrations of $\mathrm{MPP}^{+}$than untransfected cells. Whereas in the case of $\mathrm{Ltk}^{-}$cells the response to $30 \mu \mathrm{M}$ $\mathrm{MPP}^{+}$consisted only of a transfection-specific acidification of the culture medium, there was clearly a decreased viability of transfected SK-N-MC cells in medium containing 1-10 $\mu \mathrm{M}$ MPP . There are several hypotheses for the initiation of cytotoxicity of $\mathrm{MPP}^{+}$. One relates to the effective inhibition of mitochondrial respiration by $\mathrm{MPP}^{+}$, which has been reported to be a selective complex I inhibitor in mitochondria (Nicklas et al., 1985; Poirier and Barbeau, 1985; Ramsay et al., 1986). The inhibition of the NADH ubiquinone oxidoreductase activity in complex I results in increased anaerobic glycolysis with lactate accumulation as shown in mouse neostriatal tissue slices incubated with MPP+ (Vyas et al., 1986). This could explain the 
acidification of the medium of Ltk $^{-}$cells incubated with MPP+ seen in the present study. The fact that $\mathrm{Ltk}^{-}$cells did not die if incubated with up to $300 \mu \mathrm{M}$ of $\mathrm{MPP}^{+}$whereas SK-N-MC cells expressing even less dopamine transporter showed decreased viability in presence of $10 \mu \mathrm{M} \mathrm{MPP}^{+}$points either to a greater ability of fibroblasts than that of neurons to form ATP anaerobically or to another hypothesis about mechanisms of MPP+ toxicity, that is, oxidative stress. Oxidative stress would be induced by intracellular redox cycling of $\mathrm{MPP}^{+}$, generating superoxide and toxic hydroxyl radicals (Sinha et al., 1986; Chacon et al., 1987). Our results of greater susceptibility of SK-N-MC cells than $\mathrm{Ltk}^{-}$cells to toxic effects of $\mathrm{MPP}^{+}$may be due to a different sensitivity to oxidative stress of these cell lines. It has been suggested that the nervous system is especially prone to radical damage. Its membrane lipids are very rich in polyunsaturated fatty acid side chains, which are especially sensitive to free radical attack (Halliwell, 1992), and the brain is poor in catalase activity and has only moderate amounts of superoxide dismutase and gluthatione peroxidase, enzymes that can protect against oxygen toxicity (Cohen, 1988). In fact, less basal gluthatione peroxidase activity was found in NS20Y neuroblastoma cells than in mouse L cells (Ceballos et al., 1988). The expression of the dopamine transporter in different cell lines provides a model to study the toxic mechanism of drugs that are taken up by this plasma membrane transporter inside the cell without recourse to high extracellular concentrations of these drugs, which could have nonspecific effects.

Previously, the association of $\mathrm{MPP}^{+}$toxicity and uptake was observed in cultured neurons by the protective effects of uptake blockade (Sanchez-Ramos et al., 1986) and the relationship of toxicity and dopamine uptake affinity of structural analogs of $\mathrm{MPP}^{+}$(Saporito et al., 1992). In PC12 cells, resistance to MPTP treatment leads to the selection of mutants lacking catecholamine uptake (Bitler et al., 1986). More recently, mazindol has been shown to block the MPP ${ }^{+}$-induced increase of lactic dehydrogenase release in COS cells transiently transfected with the rat dopamine transporter (Kitayama et al., 1992). Our observation that the toxicity of MPP+ ${ }^{+}$on SK-N-MC cells expressing the rat or the human dopamine transporter could be prevented by the catecholamine uptake blocker mazindol reinforces these previous findings and suggests a cause/effect relationship between the transporter and MPP ${ }^{+}$

Our study demonstrates for the first time that in cells permanently transfected with the dopamine transporter cDNA (i.e., a homogeneous population of cells), the sensitivity to toxic effects of MPP+ was dependent of the expression level of the dopamine transporter. Cells expressing a lower uptake activity withstood $1 \mu \mathrm{M}$ of MPP+ for $6 \mathrm{~d}$, a treatment that killed cells expressing higher uptake activity. Since there was also a clear uptake at $1 \mu \mathrm{M}$ of MPP ${ }^{+}$into the low-expressing cells, cells seem to be able to cope with a certain influx of the toxin. Only if this influx exceeds a certain threshold do toxic reactions become evident. Differences in the density of uptake sites per dopaminergic neuron could explain why various dopaminergic brain regions differ in their sensitivity to toxic effects of MPTP. For example, the nucleus accumbens shows a dopamine loss after MPTP (Mitchell et al., 1985) that in most studies is much smaller than that in the caudate or the putamen (Rose et al., 1989; Pifl et al., 1991). Several studies suggest a lower density of dopamine uptake sites in the nucleus accumbens or in the olfactory tubercle than in the caudate-putamen (Sershen et al., 1986; Marshall et al., 1990), quite apart from the fact that actual differences in transporter per nerve terminal could still be underestimated by binding studies of slices with labeled uptake blockers (Stamford et al., 1988; Wightman and Zimmerman, 1990).

In conclusion, the cloned dopamine transporters can confer, to neuronally derived cell lines that are permanently transfected, a susceptibility to the cytotoxic effects of low concentrations of $\mathrm{MPP}^{+}$. This provides a very flexible cellular model to study the cytotoxicity of these low doses of $\mathrm{MPP}^{+}$. There does not seem to be a decisive difference between the rat and the human dopamine transporter that could explain the differences in susceptibility of these species to irreversible damage by MPTP. Since our study demonstrated the relationship between the level of expression of transporters per cell and the manifestation of toxic effects of $\mathrm{MPP}^{+}$, it is possible that in vivo differences in the expression level of transporters per nerve terminal between different dopaminergic brain regions could explain their differences in susceptibility to MPTP exposure. Expression studies of the dopamine transporter in different cellular systems should give new insight into the vulnerability of different tissues to MPTP and, by consequence, insights into the mechanism of MPTP toxicity and possibly into the etiology of Parkinson disease.

\section{References}

Bitler CM, Zhang M-B, Howard BD (1986) PC12 variants deficient in catecholamine transport. J Neurochem 47:1286-1293.

Boyce S, Kelly E, Reavill C, Jenner P, Marsden CD (1984) Repeated administration of $N$-methyl-4-phenyl-1,2,3,6-tetrahydropyridine to rats is not toxic to striatal dopamine neurons. Biochem Pharmacol $33: 1747-1752$

Burns RS, Chiueh CC, Markey SP, Ebert MH, Jacobowitz DM, Kopin IJ (1983) A primate model of parkinsonism: sclcctive destruction of dopaminergic neurons in the pars compacta of the substantia nigra by $N$-methyl-4-phenyl-1,2,3,6-tetrahydropyridine. Proc Natl Acad Sci USA 80:4546-4550.

Ceballos I, Delabar JM, Nicole A, Lynch RE, Hallewell RA, Kamoun P, Sinet PM (1988) Expression of transfected human CuZn superoxide dismutase gene in mouse L cells and NS20Y neuroblastoma induces enhancement of glutathione peroxidase activity. Biochim Biophys Acta 949:58-64.

Chacon JN, Chedekel MR, Land EJ, Truscott TG (1987) Chemically induced Parkinson's disease: intermediates in the oxidation of 1 -methyl-4-phenyl-1,2,3,6-tetrahydropyridine to the 1-methyl-4phenyl-pyridinium ion. Biochem Biophys Res Commun 144:957964.

Chiba K, Trevor A, Castagnoli N Jr (1984) Metabolism of the neurotoxic tertiary amine, MPTP, by brain monoamine oxidase. Biochem Biophys Res Commun 120:574-578.

Cohen G (1988) Oxygen radicals and Parkinson's disease. In: Oxygen radicals and tissue injury (Halliwell $B$, ed), pp 130-135. Bethesda, MD: FASEB

D'Amato RJ, Lipman ZP, Snyder SH (1986) Selectivity of the parkinsonian neurotoxin MPTP: toxic metabolite binds to neuromelanin. Science 231:987-989.

Davis GC, Williams AC, Markey SP, Ebert MH, Caine ED, Reichert CM, Kopin IJ (1979) Chronic parkinsonism secondary to intravenous injection of meperidine analogues. Psychiatry Res 1:249-254.

Dearry A, Gingrich JA, Falardeau P, Fremeau RT Jr, Bates MD, Caron MG (1990) Molecular cloning and expression of the gene for a human $D_{1}$ dopaminc rcceptor. Nature 347:72-76.

Giros B, Sokoloff P, Martres MP, Riou JF, Emorine LJ, Schwartz JC (1989) Alternative splicing directs the expression of two D2 dopamine receptor isoforms. Nature 342:923-926.

Giros B, El Mestikawy S, Bertrand L, Caron MG (1991) Cloning and functional characterization of a cocaine-sensitive dopamine transporter. FEBS Lett 295:149-154.

Giros B, El Mestikawy S, Godinot N, Zheng K, Han H, Yang-Fen T, Caron MG (1992) Cloning, pharmacological characterization, and chromosome assignment of the human dopamine transporter. Mol Pharmacol 42:383-390. 
IIalliwell B (1992) Reactive oxygen species and the central nervous system. J Neurochem 59:1609-1623.

Heikkila RE, Hess A, Duvoisin RC (1984a) Dopaminergic neurotoxicity of 1-methyl-4-phenyl-1,2,3,6-tetrahydropyridine in mice. Science 224:1451-1453.

Heikkila RE, Manzino L, Cabbat FS, Duvoisin RC (1984b) Protection against the dopaminergic neurotoxicity of 1-methyl-4-phenyl-1,2,5,6tetrahydropyridine by monoamine oxidase inhibitors. Nature 311: $467-469$.

Javitch JA, Blaustein RO, Snyder SH (1984a) $\left[{ }^{3} \mathrm{H}\right]$ mazindol binding associated with neuronal dopamine and norepinephrine uptake sites. Mol Pharmacol 26:35-44.

Javitch JA, Uhl GR, Snyder SH (1984b) Parkinsonism-inducing neurotoxin, $N$-methyl-4-phenyl-1,2,3,6-tetrahydropyridine: characterization and localization of receptor binding sitcs in rat and human brain. Proc Natl Acad Sci USA 81:4591-4595.

Javitch JA, D'Amato RJ, Strittmatter SM, Snyder SH (1985) Parkinsonism-inducing neurotoxin, $N$-methyl-4-phenyl-1,2,3,6-tetrahydropyridine: uptake of the metabolite $N$-methyl-4-phenylpyridine by dopamine neurons explains selective toxicity. Proc Natl Acad Sci USA 82:2173-2177.

Kalaria RN, Harik SI (1987) Blood-brain barrier monoamine oxidase: enzyme characterization in cerebral microvessels and other tissues from six mammalian species, including human. J Neurochem 49: 856-864.

Kilty JE, Lorang D, Amara SG (1991) Cloning and expression of a cocaine-sensitive dopamine transporter. Science 254:578-579.

Kitayama S, Shimada S, Uhl GR (1992) Parkinsonism-inducing neuroloxin $\mathrm{MPP}^{+}$: uptake and toxicity in nonneuronal COS cells expressing dopamine transporter cDNA. Ann Neurol 32:109-111.

Langston JW, Ballard P, Tetrud JW, Irwin I (1983) Chronic parkinsonism in humans due to a product of meperidine-analog synthesis. Science 219:979-980.

Langston JW, Forno LS, Rebert CS, Irwin I (1984) Selective nigral toxicity after systemic administration of 1-methyl-4-phenyl-1,2,5,6tetrahydropyridine (MPTP) in the squirrel monkey. Brain Res 292: 390-394.

Markey SP, Johannessen JN, Chiueh CC, Burns RS, Herkenham MA (1984) Intraneuronal generation of a pyridinium metabolite may cause drug-induced parkinsonism. Nature 311:464-467.

Marshall JF, O'Dell SJ, Navarrete R, Rosenstein AJ (1990) Dopamine high-affinity transport site topography in rat brain: major differences between dorsal and ventral striatum. Neuroscience 37:11-21.

Mayer RA, Kindt MV, Heikkila RE (1986) Prevention of the nigrostriatal toxicity of 1-methyl-4-phenyl-1,2,3,6-tetra-hydropyridine by inhibitors of 3,4-dihydroxyphenylethylamine transport. J Neurochem 47:1073-1079.

McPherson GA (1985) Analysis of radioligand binding experiments: a collection of computer programs for the IBM PC. J Pharmacol Methods 14:213-228.

Melamed E, Rosenthal J, Cohen O, Globus M, Uzzan A (1985) Dopamine but not norepinephrine or serotonin uptake inhibitors protect mice against neurotoxicity of MPTP. Eur J Pharmacol 116:179-181.

Mitchell IJ, Cross AJ, Sambrook MA, Crossman AR (1985) Sites of the neurotoxic action of 1-methyl-4-phenyl-1,2,3,6-tetrahydropyridine in the macaque monkey include the ventral tegmental area and the locus coeruleus. Neurosci Lett 61:195-200.

Nicklas WJ, Vyas I, Heikkila RE (1985) Inhibition of NADH-linked oxidation in brain mitochondria by 1-methyl-4-phenyl-pyridine, a metabolite of the neurotoxin, 1-methyl-4-phenyl-1,2,3,6-tetrahydropyridine. Life Sci 36:2503-2508.

O'Carroll A-M, Tipton KF, Sullivan JP, Fowler CJ, Ross SB (1987) Intra- and extraneuronal deamination of dopamine and noradrenaline by the two forms of human brain monoamine oxidase. Implications for the neurotoxicity of $N$-methyl-4-phenyl-1,2,3,6-tetrahydropyridine in man. Biogenic Amines 4:165-178.

Pacholczyk T, Blakely RD, Amara SG (1991) Expression cloning of a cocaine- and antidepressant-sensitive human noradrenaline transporter. Nature 350:350-354.

Pifl C, Schingnitz G, Hornykiewicz O (1991) Effect of 1-methyl-4phenyl-1,2,3,6-tetrahydropyridine on the regional distribution of brain monoamines in the rhesus monkey. Neuroscience 44:591-605.

Pileblad E, Carlsson A (1985) Catecholamine-uptake inhibitors prevent the neurotoxicity of 1-methyl-4-phenyl-1,2,3,6-tetrahydropyridine (MPTP) in mouse brain. Neuropharmacology 24:689-692.
Poirier J, Barbeau $\Lambda$ (1985) 1-Methyl-4-phenyl-pyridinium-induced inhibition of nicotinamide adenosine dinucleotide cytochrome $\mathrm{c}$ reductase. Neurosci Lett 62:7-11.

Ramsay RR, Salach JI, Dadgar J, Singer TP (1986) Inhibition of mitochondrial NADH dehydrogenase by pyridine derivatives and its possible relation to experimental and idiopathic parkinsonism. Biochem Biophys Res Commun 135:269-275.

Ricaurte GA, Langston JW, DeLanney LE, Irwin I, Brooks JD (1985) Dopamine uptake blockers protect against the dopamine depleting effect of 1-methyl-4-phenyl-1,2,3,6-tetrahydropyridine(MPTP) in the mouse striatum. Neurosci Lett 59:259-264.

Richelson E, Pfenning M (1984) Blockade by antidepressants and related compounds of biogenic amine uptake into rat brain synaptosomes: most antidepressants selectively block norepinephrine uptakc. Eur J Pharmacol 104:277-286.

Rose S, Nomoto M, Jackson EA, Gibb WRG, Jenner P, Marsden CD (1989) Treatment with a selective MAO B inhibitor prevents loss of dopamine in the nucleus accumbens of MPTP-treated common marmosets. Neuropharmacology 28:1211-1216.

Rotman B, Papermaster BW (1966) Membrane properties of living mammalian cells as studied by enzymatic hydrolysis of fluorogenic esters. Proc Natl Acad Sci USA 55:134-141.

Sahgal A, Andrews JS, Biggins JA, Candy JM, Edwardson JA, Keith AB, Turner JD, Wright C (1984) $N$-methyl-4-phenyl-1,2,3,6-tetrahydropyridine (MPTP) affects locomotor activity without producing a nigrostriatal lesion in the rat. Neurosci Lett 48:179-184.

Salach JI, Singer TP, Castagnoli N Jr, Trevor A (1984) Oxidation of the neurotoxic amine 1-methyl-4-phenyl-1,2,3,6-tetrahydropyridine (MPTP) by monoamine oxidases $\mathrm{A}$ and $\mathrm{B}$ and suicide inactivation of the enzymes by MPTP. Biochem Biophys Res Commun 125:831835.

Sanchez-Ramos J, Barrett JN, Goldstein M, Weiner W, Hefti F (1986) 1-Methyl-4-phenylpyridinium ( $\mathrm{MPP}^{+}$) but not 1-methyl-4-phenyl1,2,3,6-tetrahydropyridine (MPTP) selectively destroys dopaminergic neurons in cultures of dissociated rat mesencephalic neurons. Neurosci Lett 72:215-220.

Saporito MS, Heikkila RE, Youngster ST, Nicklas WJ, Geller HM (1992) Dopaminergic neurotoxicity of 1-methyl-4-phenylpyridinium analogs in cultured neurons: relationship to the dopamine uptake system and inhibition of mitochondrial respiration. J Pharmacol Exp Ther 260:1400-1409.

Schultz W, Scarnati E, Sundström E, Tsutsumi T, Jonsson G (1986) The catecholamine uptakc blocker nomifensine protects against MPTPinduced parkinsonism in monkeys. Exp Brain Res 63:216-220.

Sershen H, Mason MF, Debler EA, Lajtha A (1986) Kinetics of [ $\left.{ }^{3} \mathrm{H}\right] \mathrm{MPP}+$ uptake in dopaminergic neurons of mouse: regional effects of MPTP neurotoxicity. Eur J Pharmacol 126:337-339.

Shimada S, Kitayama S, Lin C-L, Patel A, Nanthakumar E, Gregor P, Kuhar M, Uhl G (1991) Cloning and expression of a cocaine-sensitive dopamine transporter complementary DNA. Science 254:576578.

Sinha BK, Singh Y, Krishna G (1986) Formation of superoxide and hydroxyl radicals from 1-methyl-4-phenyl-pyridinium ion $\left(\mathrm{MPP}^{+}\right)$: reductive activation by NADPH cytochrome P-450 reductase. Biochem Biophys Res Commun 135:583-588.

Stamford JA, Kruk ZL, Palij P, Millar J (1988) Diffusion and uptake of dopamine in rat caudate and nucleus accumbens compared using fast cyclic voltammetry. Brain Res 448:381-385.

Sundström E, Jonsson G (1985) Pharmacological interference with the neurotoxic action of 1 -methyl-4-phenyl-1,2,3,6-tetrahydropyridine (MPTP) on central catecholamine neurons in the mouse. Eur J Pharmacol 110:293-299.

Vyas I, Heikkila RE, Nicklas WJ (1986) Studies on the neurotoxicity of 1-methyl-4-phenyl-1,2,3,6-tetrahydropyridine: inhibition of NADlinked substrate oxidation by its metabolite, 1-methyl-4-phenylpyridinium. J Neurochem 46:1501-1507.

Wallace RA, Boldry R, Schmittgen T, Miller D, Uretsky N (1984) Effect of 1-methyl-4-phenyl-1,2,3,6-tetrahydropyridine (MPTP) on monoamine neurotransmitters in mouse brain and heart. Life Sci 35: 285-291.

Wightman RM, Zimmerman JB (1990) Control of dopamine extracellular concentration in rat striatum by impulse flow and uptake. Brain Res Rev 15:135-144. 